\title{
Undergraduate's Perception on Massive Open Online Course (MOOC) Learning to Foster Employability Skills and Enhance Learning Experience
}

\author{
Cheong Kar Mee ${ }^{1}$, Linda Khoo Mei Sui ${ }^{3}$ \\ Centre for Languages and Human Development \\ Universiti Teknikal Malaysia Melaka, \\ Malacca, Malaysia
}

\author{
Sazilah binti Salam ${ }^{2}$ \\ Fakulti Teknologi Maklumat dan Komunikasi, \\ Universiti Teknikal Malaysia Melaka, \\ Malacca, Malaysia
}

\begin{abstract}
The Massive Open Online Course (MOOC) is a very recent development in higher education institutions in Malaysia. As in September 2015, Universiti Teknikal Malaysia Melaka (UTeM) has introduced Mandarin course under Malaysia MOOCs. The study has focused on undergraduate's perception of MOOC in Mandarin subject in fostering their employability skills as a research variable. The researcher used qualitative and quantitative method as a research design. An interview was used to investigate their perception of MOOC in Mandarin subject to foster their employability skills. An online survey was also conducted to investigate the effectiveness of MOOC learning. Undergraduates in UTeM were selected as the respondents of this study. The findings show that among all the employability skill, students believe Mandarin Massive online learning course fosters two employability skills which are 'information gaining skill' and 'system and technology skill'. This study on MOOCs is important for the decision-making of the government and relevant institution to make sound decisions. This research is also significant for its contribution towards teaching practices in higher education institution.
\end{abstract}

Keywords-MOOCs; mandarin; employability skills; perception; undergraduates

\section{INTRODUCTION}

Higher education plays an integral role to produce graduates to enter the workforce. Morshidi et al. [1] indicated that "Malaysia has confirmed a target of 100,000 international students by 2010 and is currently implementing strategies to become a major exporter of higher education in the Asian region" (p.52). In education, approaches to enhance teaching and learning have always been an issue among academicians. According to Zaharim et al. [2], one of the factors that contribute to the increased unemployment rate is graduates who are not ready to enter the workforce. Feedback from the industries indicated that the communications and interpersonal skills of graduates are still below satisfactory [3]. This is supported by Cismas [4] as good presentation skill of the employee is still highly demanded in the engineering industry, business education, social and cultural sectors. Hence, as presentation skills are closely related to language which is the medium for communication, therefore there must be some effort on the enhancement of language proficiency in the higher education institution to equip the future employee with satisfactory communication skill. Omar et al. [5] also indicated that the most required soft skills sought by employers were communication skills and foreign language proficiency ranked third. It shows besides English, emphasis should be placed on foreign languages such as Mandarin language competency at the work place because of the popularity of the language.

The Massive Open Online course (MOOC) is a very recent development in the Higher education institutions (HEIs) in Malaysia. According to Dodson et al. [6], MOOCs is the domain of higher education, and the ultimate goal of MOOC is to produce quality course accessible to the mass. MOOC is a modern evolution of distance learning since 2008 [7]. According to Siemens [8], MOOC means massive (involving a huge amount of students), Open (in terms of access), Online (activities happen online), and Course (activities occur during the set times of the course offering). McAuley et al. [9] defined MOOC as 'an integration of the connectivity of social networking, the facilitation of an acknowledged expert in a field of a study, and a collection of freely accessible online resources'. Autonomy, diversity, openness, and interactivity are characteristics of a MOOC. Students can take control on their learning such as where, when, how, what and with whom they learn [10]. Universiti Teknikal Malaysia Melaka (UTeM) has also showed its effort to launch Mandarin MOOC on 7 September 2015 in order to introduce Mandarin course under Malaysia MOOCs [11]. Mandarin MOOC is an ideal selection in learning because it allows the learners to learn Mandarin in anytime and anywhere. MOOC can cater the needs of different learning community. More importantly, students found readily in learning Mandarin using MOOC [12]. As students are learning beyond the classroom activities, quality assurance on MOOC is needed for long term sustainability purpose. It is supported by Gamage et al. [13] who highlighted that many universities who create MOOCs do not pay much attention to their instructional design or the pedagogy.

This issue needs to be addressed as people will start to question on MOOCs's effectiveness due to the high dropout rates in MOOCs. It is agreed by Jordan [14] and Gamage et al. [15] as they found that the completion rate in MOOC did not exceed $20 \%$ but ranging from $7 \%$ till $13 \%$. Furthermore, learner claimed the ineffectiveness of MOOC as there is no proper mechanism to measure accurately of the user experiences in MOOC platform [16] and lack of general 
prospect of conceptualizing educational quality in higher education [17].

As Mandarin has become an important foreign language at present, the effort to introduce Mandarin MOOC to the public is an ideal decision. All the stakeholders who are responsible for Mandarin MOOC need to ensure the effectiveness of Mandarin MOOC in learning. Besides personal interest, the participation of MOOCs students could be driven by workplace requirement.

This study has focused on study the undergraduate's awareness on employability skill and their perception of Mandarin MOOC in fostering their employability skills. As employers prefer to hire competent employees who are equipped with employability skills, therefore, undergraduates should aware of the employability skills needed at the workplace. These two areas of study enable the researcher to find out the enhancement method to increase graduate employability skills in UTeM. The study on MOOCs is important for the decision-making of the government and relevant institution to make sound decisions. This research is also significant for its contribution towards teaching practices in higher education institutions.

\section{RELATED WORK}

Employability skills are influenced by many different factors [18]. Existing models include (Business, Industry and Higher Education Collaboration Council [BIHECC] 2007) [19], Work-Integrated Learning [20] highlighted certain skills that can be integrated into curriculum to foster graduates' employability skills. The skills include team working, communication, self-management and analytical skills. In Malaysia, Singh and Singh [21] conducted a study on Malaysian graduates' employability skills from the employers' perceptions and graduates' perceptions. The employability skills studied include communication skills, English proficiency, ICT skills, interpersonal skills, team working skills, leadership skills, problem solving skills, adaptability skills, risk taking skills, creativity skills, and personal organization \& time management skills. In 2012, Rasul and Rauf [22] and Rasul et.al [23], proposed an employability skills assessment tool for technical graduates. The skills proposed were interpersonal skills, thinking skills, personal qualities/values, resource skills, system and technology skills, basic skills and informational skills. Later research by Collet et.al. [24] proposed employability skills from knowledge-based industry perspectives. The skills are knowledge/learning, enterprise leadership, business function, technical management, team worker, interprofessional collaboration, leadership, life-long learning, progress/innovation skills, and create skills.

From Work Integrated Learning, 21st Century Learning until Knowledge-Based Industry Perspectives, employability skills were proposed depending on various factors and requirements. To the best of researcher's knowledge, researches on employability skills in relation to MOOC learning have not been done before. Thus, to suit the samples from technical university, the researchers have chosen employability skills model as proposed by Rasul \& Rauf [22] or Rasul et. al. [23] in the study.

\section{METHODOLOGY}

\section{A. Procedures}

In this study, qualitative and quantitative approaches were used. The research was carried out to Mandarin MOOC learners delivered via blended learning mode to 231 students at Universiti Teknikal Malaysia Melaka (UTeM). There are 44 eactivities and one e-assessment (report writing and group project video submission) offered in Mandarin MOOC. Marks obtained from 18 e-activities were counted as $10 \%$ of students' course work.

For qualitative approach, the researchers used single case single issue (SCSS) as methodological position. Case study allowed the researchers to study in depth by focusing on only eight UTeM's undergraduates as informants. This research approach is supported by Liyanagunawardena et al. [25] who found that most researches in MOOC have investigated the learner's perspective. It shows that the researchers value the learner's achievement throughout the learning process via MOOC. The selection of respondents was purposeful sampling method. The respondents were the students who registered for Mandarin course for duration of 14 weeks in their second semester 2015. The research design used in this study was qualitative in nature and interview method was used to capture and focus on the targeted scope of study. Respondents were well informed of the objective of the research. They were assured about the confidentiality of their responses and that the data would only be utilized for the purpose of this study. Consent letters were given to the informants before the interview started and the explanation of the objectives of the interview was done.

For quantitative approach, an online survey was distributed to all Mandarin MOOC students enrolled during the semester.

\section{B. Instrument}

The interview questionnaire was suitable for the target setting and respondents which the content, form, and the nature of the questions were at the satisfactory level. The reliability and validity of the interview questions have been proven by the experts. The length of time to complete the interview question was within ten minutes for each respondent in one-to-one manner. The semi-structured interview was adopted to permit an open exploration which allowed the participants to provide any information or interpretation if necessary. The interview started with the opening statement from the researcher, and finally the direct question to get the data for the research questions. Additional questions were added to follow up or to clarify the responses given by the students. The researcher also makes sure the appropriate order of the interview question asked during the interview session. There was only one interview for each respondent. This decision made by the researcher where there were no new insights or information as the information has been saturated.

The online survey was used to find out students' perception on the effectiveness of learning through MOOC. It comprised of two parts: Part 1 is demography items where students were required to give perceptions on their overall course experience and understanding of the MOOC lessons before and after taking the MOOC. The items are measured using a likert scale 
from 1 to 5 (1-Poor; 2-Fair; 3-Good; 4-Very Good; 5Excellent) options. Part 2 consists of 31 items classified into 4 constructs: Learning Design (LD), Content Design (CD), Learning Attitude (LA), and Enhancement in Teaching \& Learning $(\mathrm{E})$. The items are measured using a likert scale from 1 to 5 (1-Completely Disagree; 2-Somewhat Disagree; 3Somewhat Agree; 4-Strongly Agree; 5-Completely Agree) options.

\section{Analysis}

Interview questions were analyzed using thematic analysis at individual response level. Responses were also grouped by degree type to identify any trends in themes. Data gathered using online survey was analyzed at the end of the semester.

For the on-line survey, a total of 123 responses identified as valid responses were analyzed.

\section{RESULTS AND DISCUSSION}

This section presents the results of the study. The study was carried based on the conceptual framework shown in Fig. 1.

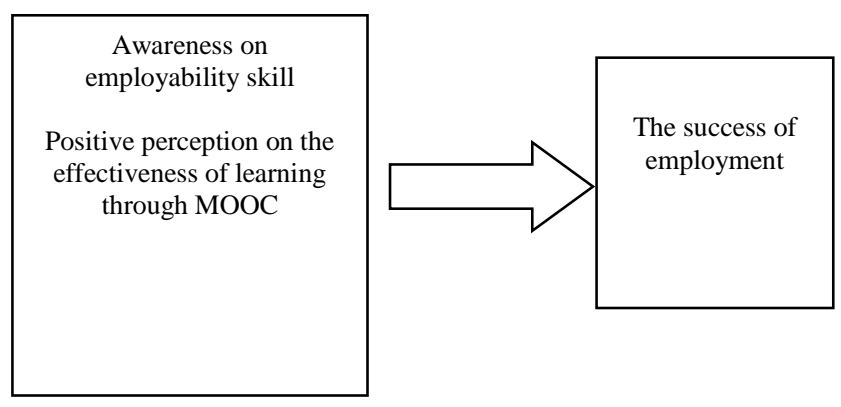

Fig. 1. The Relationship Among Variables.

Interviews were conducted in English and the transcriptions of the interviews were based on their original given information. Analysis followed the principle of grounded theory by searching the transcripts for common themes or categories. The measurement scale on employability skills developed by Rasul and Rauf [22][23] was used as a check list to examine the undergraduate's awareness of the employability skills. Besides, undergraduate's perception on Mandarin MOOC in fostering their employability skill was investigated.

\section{A. Undergraduate's Awareness on Employability Skill}

In the interview, undergraduates indicated that they were aware of the importance of employability skills as shown in Table I.

Five out of eight respondents indicated that they were aware of the importance of employability skills such as 'positive attitude like hardworking' stated by student 3, 'thinking skill which shows how we solve the problem and 'information gaining skill like how they find information online' stated by student 4, 'system and technology skill like they know how to use the technology when they are working' or 'technologically incline, they have to know their skill on using technology' stated by student 4 and student 5 , and 'good in language' or 'communication skill' stated by student 3 , student 5 and student 7.
TABLE I. UNDERGRADUATE'S AWARENESS ON EMPLOYABILITY SKILLS

\begin{tabular}{|l|l|}
\hline Respondent & \multicolumn{1}{|c|}{ Statement of Comment } \\
\hline student 2 & Skill is important in employment. \\
\hline student 3 & $\begin{array}{l}\text { The employee must have positive attitude like } \\
\text { hardworking and good in language }\end{array}$ \\
\hline student 4 & $\begin{array}{l}\text { I think the employer will want to have employee with } \\
\text { thinking skill, it shows how we solve the problem and } \\
\text { next is information gaining skill like how they find } \\
\text { information online and last is system and technology skill } \\
\text { like they know how to use the technology when they are } \\
\text { working }\end{array}$ \\
\hline student 5 & $\begin{array}{l}\text { Every future employer will want their worker to be } \\
\text { technologically incline, they have to know their skill on } \\
\text { using technology but at the same time they would love to } \\
\text { look at them on their communication skills also because } \\
\text { we can't only base them by technology but if they can't } \\
\text { present themselves }\end{array}$ \\
\hline student 7 & $\begin{array}{l}\text { The important element in employability skill is } \\
\text { communication. }\end{array}$ \\
\hline
\end{tabular}

B. Undergraduate's Perception on the Effectiveness of Online Learning Experiences

There is a significant change of higher institution from the traditional role due to globalization. MOOC is one of the online learnings which will improve teaching, and encourage the institution to develop mission [26]. The initiative by UTeM to introduce Mandarin MOOC is to keep abreast with the 21st century learning requirement. In the process of planning Mandarin MOOC, learner's prior learning experience must be considered to ensure the successful of an initiative. The respondents have reported that they have experience in online learning and have used online learning in some courses taught in UTeM such as Tamadun Islam and Tamadun Asia (TITAS) and entrepreneurship. Their statements are as follows.

"I have experience using online learning for the TITAS Tamadun Islam and Tamadun Asia subject.” (Student 1)

"Last semester I have used online learning when I learn TITAS subject. The lecturer has introduced the class to use this online learning for revision. Sometimes the lecturer also wants our class member to discuss online.” (Student 2) 3)

"In semester 1, I used MOOC to study TITAS." (Student

"I have used online learning for TITAS subject last semester." (Student 4)

"I have used online learning for TITAS and also technology entrepreneurship." (Student 5)

"I have used online learning, one of the subject was entrepreneurship.” (Student 6)

"I have used online learning for industrial engineering subject." (Student 7)

"I have used online learning, one of it is entrepreneurship another one is project management. Actually UTeM also have their own online learning system for student which is called ULearn." 
According to Bruff et al. [27], flexibility, customization, and accessibility are three of the encouraging elements in an online learning for students to have self-paced learning. The above experiences mentioned by undergraduates in the online learning proved that it is a good foundation to allow them to explore the new learning subject through online learning such as MOOCs.

Data gathered from the online survey were analyzed to see the effectiveness of using MOOC to students learning. From a total of 231 students, 123 were identified as valid responses and analyzed. Results of Part I: demography analysis showed that overall, more than $90 \%$ of the students agree that course experience are good (Excellent-19.5\%, 35\%-Very Good, $38.2 \%$-Good) and students understanding after using MOOC had increased $10.6 \%$ to Excellent, $36.6 \%$ to Very Good, and $8.9 \%$ to Good.

Analysis from Learning Design dimension shows that majority students decided that learning design is between Very Good and Good as shown in the following Table II.

\section{TABLE II. LEARNING DESIGN DIMENSION}

\begin{tabular}{|l|l|l|l|}
\hline \multicolumn{2}{|l|}{ Learning Design } & Mean & SD \\
\hline & Item & 3.87 & 0.78 \\
\hline LD1 & The course is well designed & 3.85 & 0.74 \\
\hline LD2 & Learning through MOOC meets my learning needs \\
\hline LD3 & $\begin{array}{l}\text { The sequence of learning activities help my } \\
\text { understanding of the subject matter }\end{array}$ & 3.91 & 0.74 \\
\hline LD4 & $\begin{array}{l}\text { The learning schedule (course plan/lesson plan) suits } \\
\text { my learning pace }\end{array}$ & 3.88 & 0.81 \\
\hline
\end{tabular}

Table III shows Content Design aspect where the data shows that majority respondents chose between Somewhat Agree and Strongly Agree where the course materials cover the essential aspects of the course (CD1: 3.95), The course materials is well organized (CD2: 4.00), the course materials are clear (CD3: 4.05), the course activities able to enhance their understanding of the topic covered, Overall, the course materials help their understanding of the topics covered (CD4: 3.94, CD5: 3.98), the course materials provided meet their learning needs, the course activities provided meet their learning needs (CD6: 3.95, CD7:3.97), and useful for student's learning (CD81-83: 4.15, 4.13, 4.17; CD91-94: 3.59, 3.3, 3.46, 3.53).

Table IV shows the dimension from the Learning Attitude. The research analysis shows that majority respondents agree that they can follow the course at their own pace (LA1: 3.8), accomplish the course activities on their own (LA2: 3.83), learning using MOOC, allows personalization (students can interact one-to-one with the instructor) (LA3: 3.8), and respondents engage more with lecture video and dialogue video to understand better (LA4-5: 4.06, 3.97).
TABLE III. CONTENT DESIGN

\begin{tabular}{|c|c|c|c|c|}
\hline \multicolumn{5}{|c|}{ Content Design } \\
\hline & \multicolumn{2}{|l|}{ Item } & Mean & SD \\
\hline CD1 & \multicolumn{2}{|c|}{$\begin{array}{l}\text { The course materials covers the essential aspects of } \\
\text { the course }\end{array}$} & 3.95 & 0.77 \\
\hline $\mathrm{CD} 2$ & \multicolumn{2}{|c|}{ The course materials is well organized } & 4.00 & 0.71 \\
\hline CD3 & \multicolumn{2}{|c|}{ Overall, the course materials are clear } & 4.05 & 0.73 \\
\hline CD4 & \multicolumn{2}{|c|}{$\begin{array}{l}\text { Overall, the course activities able to enhance my } \\
\text { understanding of the topic covered }\end{array}$} & 3.94 & 0.78 \\
\hline CD5 & \multicolumn{2}{|c|}{$\begin{array}{l}\text { Overall, the course materials help my } \\
\text { understanding of the topics covered }\end{array}$} & 3.98 & 0.76 \\
\hline CD6 & \multicolumn{2}{|c|}{$\begin{array}{l}\text { The course materials provided meet my learning } \\
\text { needs }\end{array}$} & 3.95 & 0.75 \\
\hline CD7 & \multicolumn{2}{|c|}{$\begin{array}{l}\text { The course activities provided meet my learning } \\
\text { needs }\end{array}$} & 3.97 & 0.79 \\
\hline CD81 & \multirow{3}{*}{$\begin{array}{l}\text { The following course } \\
\text { materials (e-content) are } \\
\text { useful for my learning: }\end{array}$} & Lecture video & 4.15 & 0.79 \\
\hline CD82 & & Dialog video & 4.13 & 0.80 \\
\hline CD83 & & Lecture slide & 4.17 & 0.73 \\
\hline CD91 & \multirow{4}{*}{$\begin{array}{l}\text { The following course } \\
\text { activities (e-activities) are } \\
\text { useful for my learning: }\end{array}$} & Quiz & 3.59 & 1.09 \\
\hline CD92 & & Essay writing & 3.3 & 1.00 \\
\hline CD93 & & $\begin{array}{l}\text { Self-video } \\
\text { presentation }\end{array}$ & 3.46 & 1.07 \\
\hline CD94 & & $\begin{array}{l}\text { Listening } \\
\text { assessment } \\
\text { (audio) }\end{array}$ & 3.53 & 1.03 \\
\hline
\end{tabular}

TABLE IV. LEARNING ATTITUDE

Learning Attitude

\begin{tabular}{|l|l|l|l|}
\hline & Item & Mean & SD \\
\hline LA1 & I am able to follow the course at my own pace & 3.8 & 0.75 \\
\hline LA2 & $\begin{array}{l}\text { I am able to accomplish the course activities on my } \\
\text { own }\end{array}$ & 3.83 & 0.73 \\
\hline LA3 & $\begin{array}{l}\text { Learning using MOOC, allows personalization } \\
\text { (students can interact one-to-one with the instructor) }\end{array}$ & 3.8 & 0.75 \\
\hline LA4 & $\begin{array}{l}\text { I engage more with lecture video to understand } \\
\text { better }\end{array}$ & 4.06 & 0.77 \\
\hline LA5 & $\begin{array}{l}\text { I engage more with dialogue video to understand } \\
\text { better }\end{array}$ & 3.97 & 0.77 \\
\hline
\end{tabular}

The Enhancement in Teaching and Learning in Table V shows the data that majority respondents chose Somewhat Agree and Strongly Agree that MOOC enhances their learning experience (E1: 3.97), Learning via MOOC is enjoyable (E2: 4.02), they learn more effective using MOOC (E3: 3.98), students are satisfied in learning using Mandarin MOOC (E4: 4.06), students believe the use of MOOC for learning Mandarin is feasible (E5: 4.07), and learning via MOOC help the students to remember, understand, and apply learning more effectively (E61-3: 4.11, 4.13, 4.12). 
TABLE V. ENHANCEMENT IN TEACHING AND LEARNING

\begin{tabular}{|c|c|c|c|c|}
\hline \multicolumn{5}{|c|}{ Enhancement in T\&L } \\
\hline & \multicolumn{2}{|l|}{ Item } & Mean & SD \\
\hline E1 & \multicolumn{2}{|c|}{ MOOC enhances my learning experience } & 3.97 & 0.83 \\
\hline E2 & \multicolumn{2}{|c|}{ Learning via MOOC is enjoyable } & 4.02 & 0.79 \\
\hline E3 & \multicolumn{2}{|c|}{ I learn more effective using MOOC } & 3.98 & 0.81 \\
\hline $\mathrm{E} 4$ & \multicolumn{2}{|c|}{$\begin{array}{l}\text { Overall, I am satisfied in learning using Mandarin } \\
\text { MOOC }\end{array}$} & 4.06 & 0.84 \\
\hline E5 & \multicolumn{2}{|c|}{$\begin{array}{l}\text { I believe the use of MOOC for learning Mandarin is } \\
\text { feasible }\end{array}$} & 4.07 & 0.79 \\
\hline E61 & \multirow{3}{*}{$\begin{array}{l}\text { Learning via MOOC } \\
\text { help me to: }\end{array}$} & Remember (facts) & 4.11 & 0.69 \\
\hline E62 & & $\begin{array}{l}\text { Understand (concepts, } \\
\text { principles, processes) }\end{array}$ & 4.13 & 0.71 \\
\hline E63 & & Apply (what I have learned) & 4.12 & 0.69 \\
\hline
\end{tabular}

C. Undergraduate's Perception on the Effectiveness of Mandarin Massive Open Online Course in Fostering their Employability Skills

The findings of Cranmer [28] cast doubt on the assumption that employability skills can be effectively developed within classrooms. It shows there are limitations of face to face teaching and learning approach. Realizing this, besides face to face approach, online course such as Mandarin MOOC could play a good role to foster graduate's employability skills.

According to Fadzil et al. [29], the reasons for adoption of MOOCs in higher education institutions are to provide quality education to everyone, promoting an institution's brand, attracting new learners to enroll at an institution, potential for collaborating with other institutions, potential for research and development in online education as well as transforming traditional teaching and learning approaches. In the interview, undergraduates indicated that they have positive perception on the effectiveness of Mandarin MOOC in fostering their employability skills. The data is presented in the Table VI.

TABLE VI. UNDERGRADUATE'S PERCEPTION ON THE EFFECTIVENESS OF MANDARIN MASSIVE OPEN ONLINE COURSE IN FOSTERING THEIR EMPLOYABILITY SKILLS

\begin{tabular}{|l|l|l|l|l|l|l|l|l|}
\hline \multirow{2}{*}{$\begin{array}{l}\text { The effectiveness of } \\
\text { Mandarin Massive Open } \\
\text { Online Course in fostering } \\
\text { employability skills }\end{array}$} & \multicolumn{7}{|c|}{ Students } \\
\cline { 2 - 9 } & $\mathbf{1}$ & $\mathbf{2}$ & $\mathbf{3}$ & $\mathbf{4}$ & $\mathbf{5}$ & $\mathbf{6}$ & $\mathbf{7}$ & $\mathbf{8}$ \\
\hline Basic skill & & & & & & & & \\
\hline Thinking skill & & & & & & & & \\
\hline Resource Management skill & & & & & & & & \\
\hline Information Gaining skill & $\mathrm{xx}$ & $\mathrm{xx}$ & $\mathrm{xx}$ & $\mathrm{xx}$ & & & & $\mathrm{xx}$ \\
\hline Interpersonal skill & & & & & & & & \\
\hline System and Technology skill & & $\mathrm{xx}$ & & $\mathrm{xx}$ & $\mathrm{xx}$ & $\mathrm{xx}$ & $\mathrm{xx}$ & $\mathrm{xx}$ \\
\hline Personal quality & & & & & & & & \\
\hline
\end{tabular}

Yorke and Knight [30] stressed that those who has desire to design new curriculum has to consider the potential of their program to develop students' employability skills. Among all the employability skills, students believe Mandarin MOOC fosters two employability skills which are 'information gaining skill' and 'system and technology skill'. Five out of eight students have showed their positive perception on the effectiveness of Mandarin MOOC in fostering their information gaining skill. It is supported by Carver and Harrison [31] that the MOOC's collaborative design incorporates opportunities to encourage cultural exchange and reinforce diverse approaches to problem solving. Students enjoy the learning experiences especially opportunity given to search information through internet. These findings show that Mandarin MOOC could play a good role to foster graduate's employability skills.

\section{CONCLUSION}

The Higher Education Institution in the world is constantly changing in pursue of quality, recognition and progression to become world class higher education provider. Engagement technology in education will create new learning environment where emphasis is on student-centered learning, constructivist and collaborative learning. Research shows that active learning using ICT approach is a new trend in higher education [32]. The use of computer and internet is a necessity in order to create a quality learning environment. The importance of a quality learning environment is to ensure that students would not left out from the world of technology.

In Malaysia, education is the biggest challenge for the government and education is a way to make year 2020 become a reality. How to produce well equipped citizen with education is always a question which is needed to be answered. One solution is to use technology as a medium or a new teaching approach in order to bring education to the masses. Higher education has to change because it needs more innovation for today's need [33]. Some existing traditional public universities or private universities and colleges have worked out to take up this challenge by utilizing the latest technologies to improve the delivery systems. Their effort results a new learning system in Malaysia which is MOOC. According to Renz et al. [34], instructional designer should contribute in MOOC to enable steady improvement of the media and content platform.

This study has managed to answer the research questions which show that the undergraduates are aware of the employability skills needed at the work place. They are found to have good foundation of online learning experiences. Besides, they have showed their positive perceptions on effectiveness of Mandarin MOOC which can foster their employability skills such as information gaining skill as well as system and technology skill. The limitation of this study is only eight respondents were chosen for an interview which lasted for 10 minutes each. This study is significant in determining the content of Mandarin MOOC material which may lead to an effective learning process. Future studies should focus on more variables to enhance performance in learning. To evaluate the effectiveness of Mandarin MOOC in fostering undergraduate's employability skill, more researches should be done to evaluate 
whether this course can address the need of the diverse population.

\section{ACKNOWLEDGMENT}

This research was conducted by Pervasive Computing and Educational Technology (PET) Research Group, C-ACT, Universiti Teknikal Malaysia Melaka (UTeM). The authors wish to record thanks to the Council of Public Higher Education Institutions e-Learning Coordinators of Malaysia (MEIPTA) and Open Learning in collaboration with the Centre for Instructional Resources \& Technology, UTeM in the development of Malaysia MOOCs Analytic Dashboard (https://mooc.utem.edu.my/mymooc).

\section{REFERENCES}

[1] S . Morshidi, B. Rosni, and Y. L. Koo, "International student mobility Malaysia." in the international mobility of students in Asia and the Pacific. France: The United Nations Educational, Scientific and Cultural Organization, 2013.

[2] A. Zaharim, Y. M. Yusoff, M. Z. Omar, A. Mohamed, N. Muhamad, and R. Mustapha, "Perceptions and expectation toward Engineering graduates by employers: a Malaysian study case," Wseas Transactions on Advances in Engineering Education, vol. 6(9), 2009, pp. 296-305.

[3] M. Y. Yuzainee, A. Zaharim, and M. Z. Omar, "Employability skills for an entry-level engineer as seen by Malaysian employers," in Global Engineering Education Conference (EDUCON) IEEE, 2011, pp. 80-85.

[4] S. C. Cismas, "Globalization in Engineering Education: advances in teaching presentation skills," in 6th WSEAS International Conference on Engineering Education, 2009, pp. 236-240.

[5] N. H. Omar, A. A. Manaf, R. H. Mohd, A. C. Kassim, and K. A. Aziz "Graduates' employability skills based on current job demand through electronic advertisement," Asian Social Science, vol. 8(9), 2012, pp. $103-110$.

[6] M. N. Dodson, K. Kitburi, and Z. L. Berge, "Possibilities for MOOCs in Corporate Training and Development," Performance Improvement, vol. 54(10), 2015, pp.14-21.

[7] J. Lin, and L. Cantoni, "A new definition of Massive Open Online Course: Arise from content analysis of 84 publications between 2008 and

2016".https://www.researchgate.net/profile/Jingjing_Lin/publication/31 2378247, 2017.

[8] G. Siemens, "Massive Open Online Courses: Innovation in education," Open educational resources: Innovation, research and practice, vol. 5, 2013, pp. 5-15.

[9] McAuley, B. Stewart, G. Siemens, and D. Cormier, "The MOOC model for digital practice". [Online] Available: https://s3.amazonaws.com/academia.edu.documents/43171388, 2010.

[10] J. Mackness, S. Mak, and R. Williams, "The ideals and reality of participating in a MOOC," in 7th International Conference on Networked Learning 2010. University of Lancaster, 2010, pp. 266-275.

[11] Centre for Instructional Resources \& Technology (PSTP) and Council of Public Higher Education Institutions e-Learning Coordinators of Malaysia (MEIPTA), 2018. "Malaysia MOOCs Analytic Dashboard". [Online] Available: https://mooc.utem.edu.my/mymooc/

[12] K. M. Cheong, L. M. S. Khoo, J. Zanariah, and H. Hanipah, "The readiness of the administrators and undergraduates in using Massive Open Online Course (MOOC) in the Mandarin Subject," The Social Sciences, vol. 11(12), 2016, pp. 3017-3023.

[13] D. Gamage, I. Perera, and S. Fernando, "What do star rates for MOOCs tell you? An analysis of pedagogy and review rates to identify effective pedagogical model," in W. Chen.et al. (Eds.) in 24th International Conference in Education. India: Asia-Pacific Society for computers in Education, 2016.
[14] K. Jordan, "Initial trends in enrolment and completion of Massive Open Online Courses,"The International Review of Research in Open and Distributed Learning, vol. 15(1), 2014, pp. 133-159.

[15] D. Gamage, S. Fernando, and I. Perera, "Factors leading to an effective MOOC from participiants' perspective" in Ubi-Media Computing (UMEDIA), 2015 8th International Conference, 2015, pp. 230-235.

[16] J. P. Espada, V. García-Díaz, C. Castillo Rodríguez, and R. GonzálezCrespo, "Method for analysing the user experience in MOOC platforms," in Computers in Education (SIIE), 2014 International Symposium, 2014, pp. 157-162.

[17] J. Raffaghelli, P. Ghislandi, and N. Yang, "Quality as perceived by learners: Is it the dark side of the MOOCs," Rem-Research On Eduacation and Media, vol. 6(1), 2014, pp. 121-136.

[18] L. Pool, and P. Sewell, "The key to employability: Developing a practical model of graduate employability", Education and Training, vol. 49, no. 4, 2007, pp. 277-289.

[19] (Business, Industry \& Higher Education Collaboration Council [BIHECC] 2007), "Graduate employability skills", Canberra: BIHECC.

[20] D. Jackson. 2015 "Employability skill development in work-integrated learning: Barriers and best practice", Journal Studies in Higher Education, vol. 40(2), 2015, pp. 350-367.

[21] G. K. G. Singh, and S. K. G. Singh, "Malaysian graduates' employability skills", UNITAR e-journal, vol. 4, No. 1, January 2008.

[22] M. S. Rasul, and R. A. A. Rauf, "Pembangunan alat ukur tahap kemahiran Kebolehdapatan kerja”. Penerbit Universiti Putra Malaysia, 2010.

[23] M. S. Rasul, R. A. A. Rauf, A. N. Mansor, and A. P. Puvanasvaran, "Employability skills assessment tool development", International Education Studies, vol. 5, No. 5, 2012, pp. 43-56.

[24] C. Collet, D. Hine, and K. du Plessis, "Employability skills: Perspectives from a knowledge-intensive industry", Education and Training, 57(5), 2015, pp. 532-559.

[25] T. R. Liyanagunawardena, A. A. Adams, S. A. Williams, "MOOCs: A systematic study of the published literature 2008-2012," The International Review of Research in Open and Distributed Learning, vol. 14(3), 2013, pp. 202-227.

[26] J. Daniel, "Making sense of MOOCs: Musings in a maze of myth, paradox and possibility," Journal of interactive Media in education, vol. 3, 2012.

[27] D. O. Bruff, D. H. Fisher, K. E. McEwen, B. E., Smith, "Wrapping a MOOC: Student perceptions of an experiment in blended learning," MERLOT Journal of Online Learning and Teaching, vol. 9(2), 2013, pp. 187-199.

[28] S. Cranmer, "Enhancing graduate employability: best intentions and mixed outcomes," Studies in Higher Education, vol. 31(2), 2006, pp. 169-184.

[29] M. Fadzil, L. A. Latif, and T. A. Munira, "MOOCs in Malaysia: A preliminary case study," in E-ASEM Forum: Renewing the lifelong learning agenda for the future, Bali, Indonesia, 2015, pp. 1-17.

[30] M. Yorke, and P. Knight, "Embedding employability into the curriculum", vol. 3. York: Higher Education Academy, 2006.

[31] L. Carver, and L. Harrison, "MOOCs and democratic education," Liberal Education, vol. 99(4), 2013.

[32] R. Rena, "Emerging trends of higher education in developing countries," Scientific Annals of The Alexandru Ioan Cuza University Of Iasi: Economic Sciences Series, 2010, pp. 301-316.

[33] B. Wildavsky, A. P. Kelly, and K. Carey, "Reinventing higher education: the promise of innovation," Harvard Education Press, Cambridge, 2011.

[34] J. Renz, F. Schwerer, and C. Meinel, "openSAP: Evaluating MOOC usage and challenges for scalable and open enterprise education," International Journal of Advanced Corporate Learning., vol. 9(2), 2016, pp. 34-39. 